\title{
テレメーター法による運動中の心搏週期の 変動に関する研究
}

\author{
第 2 編 \\ $50 \mathrm{~m}, 100 \mathrm{~m}$ 及ひ $400 \mathrm{~m}$ 水泳中の心搏週期の変動経過について
}

徳島大学医学部第一生理学教室 (主任 : 岡 芳包教授)

木 村 勝

（受付 昭和 45 年 5 月 10 日）

\begin{abstract}
A STUDY BY TELEMETERING ON THE VARIATION OF THE CARDIAC CYCLE DURING MUSCULAR EXERCISE PART 2 ON THE COURSE OF VARIATION OF THE CARDIAC CYCLE DURING 50, 100 AND 400 METER SWIMMING
\end{abstract}

\section{Masaru Kimura}

The First Department of Physiology, School of Medicine, Tokushima University

(Director: Prof. Y. Oka, M. D.)

Electrocardiograms during 50,100 and 400 meter swimming were recorded by means of specially designed all-transistorized underwater transmitter by modulated carrier current of high audiofrequency (about $10 \mathrm{kc} / \mathrm{s}$ ), and the course of variation of the cardiac cycle during swimming was examined.

The results may be summarized as follows.

1) The variation of the cardiac cycle was rather similar in grade to that found in the middle-long distance running than to that in the short distance running.

2) Immediately after the start or $10 \sim 15$ seconds after the start the cardiac cycle was slowly shortened, and then it stayed at a certain level for 10 20 seconds.

3) During 100 and 400 meter swimming the duration of the cardiac cycle showed the tendency of being prolonged at the turning, and, in general, as time goes in swimming, it showed the tendency of being shortened.

4) The degree of the shortening of the cardiac cycle was remarkably large in free style swimming as compared with those in breast, back and butterfly strokes.

5) It was found the differece in the variation of the cardiac cycle during 400 meter swimming between the trained and the untrained swimmers.

スポーツ医学の実験的研究は,いわゆる戦後, 即 ち 20 年余り前から盛になってきたが,その5ちで 特に注目に值すると思われるものは，新らしい方 法としてテレメータ一法を導入し, 続々新知見を 開発していることであろう。以前でも, 運動開始 直前までと終了直後からの心搏動や呼吸の動態を
調へた研究は数多く行なわれ，その結果から運動 中における呼吸循環の様相を推論しているが，こ れでは実証性に乏しいのは勿論であって, 運動中 の身体機能の実態を直接とらえる方法の開発は, この方面の研究者のひとしく渇望寸るところであ った。るっとも，位置の移動をしない運動につい 
ては，従来の方法によって，例えば運動中の心電 図を有線的に記録することも可能であるが，対象 となる運動がこく少数の特殊なものに限られるの は云うまでもない。自転車エルゴメーターやトレ ッドミルを利用することによって，この制限は僅 かに楥和されたが，この場合，運動あるいは労作 の強度や量を調整ないし規格化することができる という利点はあるすのの, 運動あるいは労作が模 型的ないし要素的であるとい 弱点はまぬがれな い。

著者らの教室では十数年前から, 実際の陸上ス ポーツ運動中, したがって又実際の一般作業動作 中の心電図や呼吸運動の模様を，短波無線搬送方 式 telemetering でとらえることを志し，得られ た知見を逐年，岡 (5)2)，宇都山(3)4)，野田5)6)，著 者7)が，主として本誌に発表してきた。同様に猪 飼ら ${ }^{8)}$ は,トレッドミル法による全身持久性の評 価の研究にテレメーター法を応用し, 叉, Hanson ら9)はテレメーター法で，スキー競技の全経過に わたる心搏数の变動を追跡した研究を報告してい る。

このように，陸上運動についてのテレメーター 法による研究は，国の内外を問わず，次第に增加 しているが，水泳など水上ないし水中の運動につ いてのテレメーター法的研究は殆んど見当らな い。それは第 1 に，在来の陸上テレメータ一方式 と装置が，水中テレメータリングにはそのまま適 用できないからである。そこで著者らの教室では， 1つの新らしい水中テレメーター方式と装置につ いて工夫と試作を重ね，これによって得られた成 果を, 岡・宇都山・野田・木村10)11)12)13)や，岡・ 宇都山14)が発表してきた。

水泳あるいは一般に水中での運動は, 環境のみ ならず，位置移動のための身体推進機構が，陸上 運動とはまるで違い，浮揚や潜水などの特殊状態 ああって, 呼吸循環機能の動態にも当然陸上運動 の場合と異なった点があると考えられる。ところ が, 水泳運動中の呼吸循環動態の研究は, 今まで 著者の知る限り殆んどない。ただ，Hunt ${ }^{15)}$ は短 距離 $(110$ ヤート $)$ 競泳の前後の 循環機能の変化 を心電図でとらえているが，テレメーター法では ないので競泳中のデータはない。又，宮下・松井 ら ${ }^{17)}$ はインターバル水泳中の心搏数を心電図記録
によって連続的に求めた成績を報告しているが， このときの心電図記録法は，導線を竿で支えた補 助者がプールサイドを泳者と平行に走るといら有 線導出方式である。

次に述べる実験と成績は, 著者らの教室独自の 方式と装置によって, $50 \mathrm{~m}, 100 \mathrm{~m}, 400 \mathrm{~m}$ の各距 離で, 自由型, 平泳, バタフライと背泳の 4 種目 の競泳について，水泳中ならびにその前後にわた って，無線搬送による心電図を連続記録し，その 結果から水泳中の心搏週期の変動経過を追求考察 したものである。

\section{实 験 方 法}

著者らの教室で考案自作した心電図の水中無線

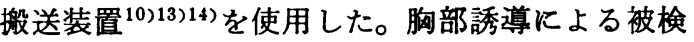
者の $\mathrm{Ekg}$ で，約 $15000 \mathrm{c} / \mathrm{s}$ の搬送波電流を周波数 变調し, 更に電力增幅して, 被検者の腰部側面に 取付けた 2 枚の送信用電極によって水中に流し， これをプールのコースロープの下，水面下数 $\mathrm{cm}$ に張った 2 本の裸銅線によって受信, 増幅してテ ープレコーダーに録音し, あとで再生, 周波数弁 別器により復調してオッシログラフに記録した。

このよ5にして得た水泳中の心電図について, その R-R 間隔を宇都山光の方式で計測し，又これ によって心搏週期の変動経過図を作製した。

実際の水泳競技では, 自由型, 平泳, 扣よび: タフライのいずれも，スタート台から飛びこんで 競技を行な5のであるが, 空気中から水中へ(又そ の逆向きに）連続的に，心電図などを無線搬送す る方法は，残念ながらまた研究途上にある。そこ でこの実験では, 各種目ともあらかじめ水中に入 り，水中からスタートするとい5方式をとらさる を得なかった。従って，後に述へる水泳開始前の 心搏週期というのは，水中での立位に扣けるもの である。

被験者は，50m 泳については年令 $21 \sim 23$ 才の 德島大学の学生ならびに一般の男子 5 名, $100 \mathrm{~m}$ 泳 については第 17 回国民体育大会德島県選手で 17 〜28 才の男子 8 名と女子 4 名， $400 \mathrm{~m}$ 泳について は第 17 回国民体育大会德島県選手 16〜19才の男 子 3 名と德島大学医学部水泳部の学生 4 名で年令 は22〜23才の合計 24 名であった。又, 水泳種目 は, $50 \mathrm{~m}$ では自由型と平泳の 2 種目， $100 \mathrm{~m}$ では 
Table 1. The temperature of the air and of the water in the swimming pool, as well as the names of swimmers with each swimming distance, in each date of the experiment.

\begin{tabular}{|c|c|c|c|c|}
\hline Date & Tempereture & $\begin{array}{l}\text { Woter tem- } \\
\text { peroture }\end{array}$ & Subject & Distence \\
\hline Sept 13.1961 & $30.0^{\circ} \mathrm{C}$ & $26.0^{\circ} \mathrm{C}$ & Nichill Kohome, Odo.Fujmure, Yoethida & $50 M$ \\
\hline Aug.20.1962 & $29.0^{\circ} \mathrm{C}$ & $25.0^{\circ} \mathrm{C}$ & Fujimuro, Abe. Inowe & \multirow{4}{*}{$100 \mathrm{M}$} \\
\hline Aug. 21. 1962 & $31,0^{\circ} \mathrm{C}$ & $25.5^{\circ} \mathrm{C}$ & Saiki,Nodo,Akita, Takouti & \\
\hline Aug.22.1962 & $30.0^{\circ} \mathrm{C}$ & $26.0^{\circ} \mathrm{C}$ & Sano,Kohere,OThba,Sughare & \\
\hline Aug. 23.J962 & $31.5^{\circ} \mathrm{C}$ & $26.5^{\circ} \mathrm{C}$ & Ishiyome & \\
\hline Aug. 22.J962 & $30.0^{\circ} \mathrm{C}$ & $26.0^{\circ} \mathrm{C}$ & Sakai, Horoda, Urogami & \multirow{2}{*}{$400 M$} \\
\hline Aug. 23.1962 & $31.5^{\circ} \mathrm{C}$ & $26.5^{\circ} \mathrm{C}$ & Nokamura.Kuromoto. Otuka, Takad & \\
\hline
\end{tabular}

自由型，平泳，背泳，バタライの 4 種目， 400 m では自由型だけについて実験した。実験日時， 気象条件等はTable 1 に示した通りである。実験 には德島大学教育学部の $25 \mathrm{~m}$ プールを使用した。

\section{実 験 成 綂}

Fig. 1 5 は, $50 \mathrm{~m}, 100 \mathrm{~m}, 400 \mathrm{~m}$ 水泳競技に ついて得た心電図の R-R 間隔の計測値から，心 搏週期の变動を経時的に示したものである。又, この変動経過図から，心搏週期の変化と，動摇の 現われるまでの時間，および動摇の振幅，持続時 間などについて計測した結果を，Table 2〜4に 示した。

1. 水泳中およひその前啳の心搏週期の一般的变化

$50 \mathrm{~m}, 100 \mathrm{~m}, 400 \mathrm{~m}$ 水泳開始前の心搏週期は 0.6 秒以上の者が多く，かなり大きい動摇が認められ る。これは呼吸性動摇と思われる。

3 種目とも，スタートと同時に，心搏㥜期には 陸上運動の疾走時にみられるような激しい動摇了) はなく，階段状に短縮（又は下降，以下同様）し つつ第 1 次下降，第 2 次下降に向い，次いで一定 のレベルを保ちつつ一定時間程過後, 第 3 次下降 に移行するものが多い。その後 steady state に達 するが，いずれす全経過を通じて，心搏週期は振
幅 $0.01 〜 0.03$ 秒の微細動摇を示しながらゴール に達する。このゴール到着直前に殆んどすべての 例で，心搏週期は steady state での值より若干延 長する傾向がある。ゴール到着後は，再び大きい 動摇をくり返しながら，全例とす水泳停止直後か ら回復に向い， 3 種目と歹大体 2 分以内に，スタ 一ト前の心搏週期の値にまで回復する。なお，タ ーンの時に心搏週期が若干延長する傾向がある が，長距離泳の場合，競泳時間の経過とともに， このターン時の心搏週期の延長は減少する。

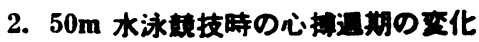

(Fig. 1, Table 2 参照)

\section{A $50 \mathrm{~m}$ 水泳開始前の心搏週期の变動}

水泳開始前の平均心搏㥜期は $0.65 \pm 0.28$ 秒（ $\alpha$ $=0.05$, 以下同様)で，心搏飔期の動摇の振幅は 9 例中 2 例が 0.02 秒，他の 7 例では 0.05〜0.25 秒 とい5よ5に著明な動摇を示すが，これらの動摇 法呼吸性動据と考えられる。水泳開始前の心搏飔 期が 0.6 秒以上の者では, 宇都山 ${ }^{3)}$ の報告と同様 に大きい呼吸性動摇を認めるが，0.5 秒以下の者 についてはこの動摇はあまり著明でない。

B $50 \mathrm{~m}$ 水永中の心搏週期の变動

i ～水泳開始直後の心搏遇期の変動

水泳開始と同時に心搏㥜期は急啟に短樎し，し 


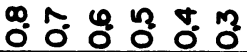

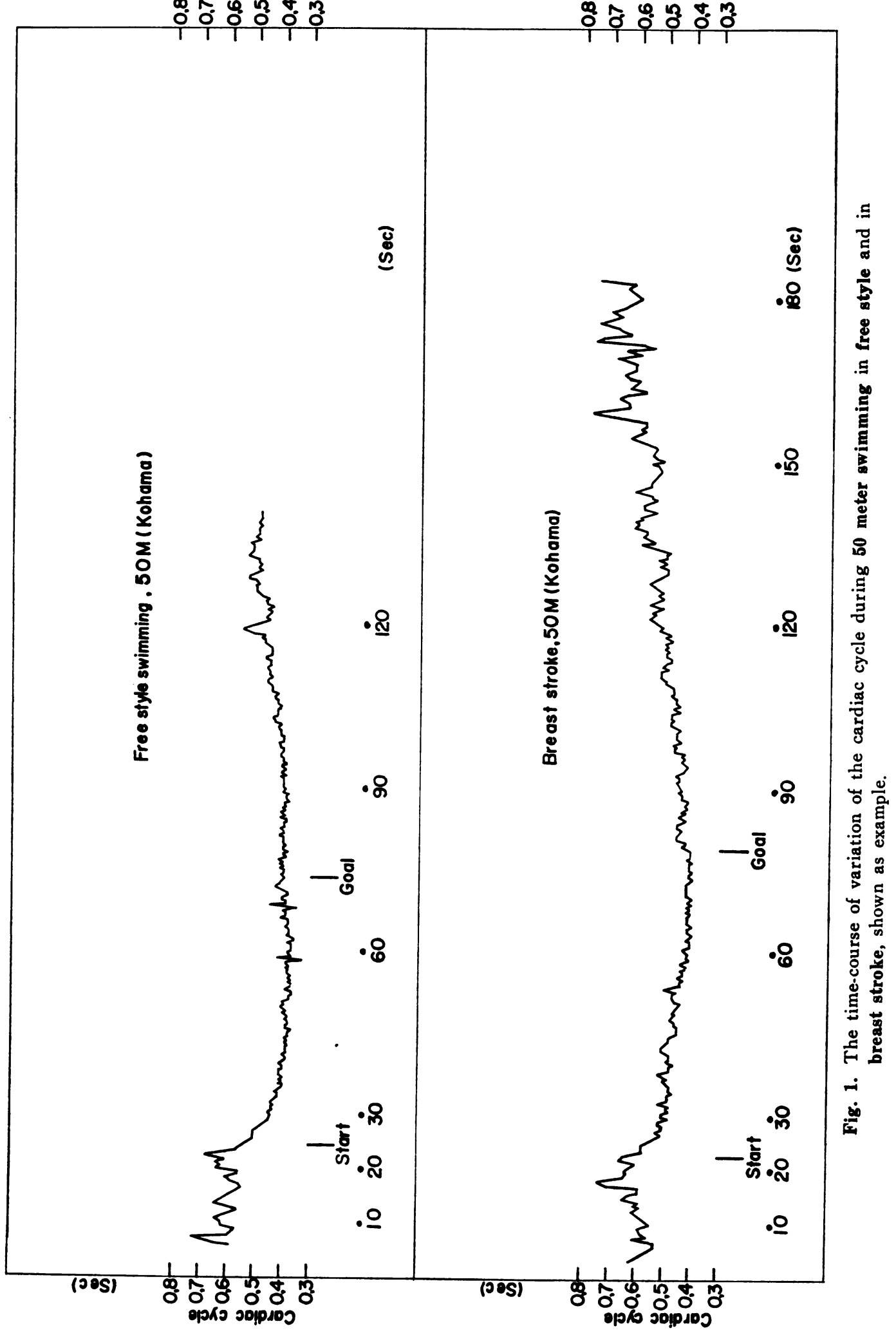


Table 2. Experimental data for $\mathbf{5 0}$ meter swimming in free style and in breast stroke.

\begin{tabular}{|c|c|c|c|c|c|c|c|c|c|c|c|}
\hline \multirow{2}{*}{\multicolumn{2}{|c|}{ Unix(Sec) }} & \multicolumn{5}{|c|}{ Free style } & \multicolumn{5}{|c|}{ Breast stroke } \\
\hline & & \begin{tabular}{|l|l|} 
Nishii & K \\
\end{tabular} & $\begin{array}{c}\text { Koha- } \\
\text { ma }\end{array}$ & Oda & \begin{tabular}{|c|c|}
$\begin{array}{c}\text { Fuji- } \\
\text { mura }\end{array}$ \\
\end{tabular} & \begin{tabular}{|c|}
$\begin{array}{c}\text { Yoshi- } \\
\text { da }\end{array}$ \\
\end{tabular} & $\begin{array}{c}\text { Koha- } \\
\text { ma }\end{array}$ & Oda & \begin{tabular}{|c|}
$\begin{array}{c}\text { Fuji- } \\
\text { muro }\end{array}$ \\
\end{tabular} & \begin{tabular}{|c|} 
Yoshi- \\
da
\end{tabular} & $\begin{array}{l}\text { Limit of rell - } \\
\text { ance }(\alpha=0.05)\end{array}$ \\
\hline \multicolumn{2}{|c|}{ Aver, cordiac cycle before stort } & 0.800 & 0.61 & 0.50 & 0.52 & 0,72 & 0.63 & 0.70 & 0.66 & 0,73 & $0,65 \pm 0,28$ \\
\hline \multicolumn{2}{|c|}{\begin{tabular}{|l} 
Amplitude of the fluctuation of cardiac \\
cycle before sfart
\end{tabular}} & 0.1210 & 0.08 & 0.02 & 0.02 & 0.25 & 0.05 & 0.07 & 0.08 & 0.17 & $0.10 \pm 0.02$ \\
\hline \multicolumn{2}{|c|}{$\begin{array}{l}\text { Terminal point of ropid shortening of } \\
\text { cordiac cycle immediately offer start }\end{array}$} & & 0.50 & & 0.46 & 0.49 & 0,58 & 0.52 & 0,49 & 0.56 & $0.53 \pm 0.08$ \\
\hline \multirow{4}{*}{$\begin{array}{l}\text { Rapld fluctuation of } \\
\text { cardiac cycle during } \\
\text { swimming }\end{array}$} & $\begin{array}{c}\text { Greatest } \\
\text { omplitude }\end{array}$ & & & & 0.72 & & & & & & \\
\hline & \begin{tabular}{|c|}
$\begin{array}{c}\text { Level of } \\
\text { amplitude }\end{array}$ \\
\end{tabular} & & & & 0,55 & & & & & & \\
\hline & \begin{tabular}{|l|} 
Time of \\
appearance \\
\end{tabular} & & & & 2.5 & & & & & & \\
\hline & $\begin{array}{l}\text { Time of } \\
\text { continuation }\end{array}$ & & & & 2,5 & & & & & & \\
\hline \multicolumn{2}{|c|}{\begin{tabular}{|c|} 
Aver. cordiac cycle immediately offer stant \\
(not repid fluctuation)
\end{tabular}} & $0.61 \mid 0$ & $0.52 \mid C$ & 0.47 & & 0.49 & 0.59 & 0.57 & 0.50 & 0.54 & $0.54 \pm 0.03$ \\
\hline \multirow{3}{*}{$\begin{array}{l}\text { Terminal point of } \\
\text { shortening of the } \\
\text { second stage }\end{array}$} & \begin{tabular}{|c|c|}
$\begin{array}{c}\text { Aver, cordloc } \\
\text { cycle }\end{array}$ & $C$ \\
\end{tabular} & 0.490 & 0.41 & 0,38 & & 0.45 & 0.48 & $0.44 C$ & 0.46 & 0.43 & $0.44 \pm 0.03$ \\
\hline & \begin{tabular}{|c|} 
Time of \\
appearance
\end{tabular} & 15 & 11 & 15 & & 8 & 9 & 14 & 8 & 10 & $11 \pm 3$ \\
\hline & \begin{tabular}{|l|l|}
$\begin{array}{l}\text { Amplitude of } \\
\text { fluctuation }\end{array}$ & 0 \\
\end{tabular} & $0.02 \mid c$ & 0.01 & 0.01 & & 0.01 & 0.03 & 0.01 & 0.01 & 0.02 & \\
\hline \multirow{2}{*}{$\begin{array}{l}\text { Steady state of } \\
\text { cordioc cycle }\end{array}$} & \begin{tabular}{|c|c}
$\begin{array}{c}\text { Aver, candiac } \\
\text { cycle }\end{array}$ & 0 \\
\end{tabular} & $0.44 \mid C$ & 0,38 & 0.36 & & 0,40 & 0.41 & 0,38 & 0.41 & 0.40 & $0.39 \pm 0.07$ \\
\hline & \begin{tabular}{|c|c|} 
Time of \\
oppearonce
\end{tabular} & 39,32 & 26.5 & 43.0 & & 39.0 & 36.0 & 60.0 & 74,5 & 45,0 & $45.0 \pm 13.0$ \\
\hline \multicolumn{2}{|c|}{$\begin{array}{l}\text { Amplitude of the fluctuation of cardiac } \\
\text { cycle in the steody state }\end{array}$} & $0.01 \mid c$ & 0.01 & 0.01 & & 0.02 & 0.02 & 0.01 & 0.01 & 0.01 & \\
\hline \multicolumn{2}{|c|}{ Minimum cardiac cycle during swimming } & $0.43 \mathrm{C}$ & 0.32 & 0.34 & 0.34 & 0.38 & 0.40 & 0.37 & 0.39 & 0.39 & \\
\hline \multirow{3}{*}{$\begin{array}{l}\text { Aver, minimum cordiac } \\
\text { cycle during swimming }\end{array}$} & Cardiac cycle & $0.44 \mathrm{C}$ & 0,37 & 0.35 & 0,39 & 0.40 & 0.41 & 0.38 & 0,40 & 0.39 & $0,39 \pm 0,02$ \\
\hline & Time of & 39 & 34 & 33 & 49 & 40 & 38 & 60 & 70 & 55 & $48 \pm 13$ \\
\hline & \begin{tabular}{|c|} 
Time of \\
continuation
\end{tabular} & 6.0 & 10 & 5,0 & 2.5 & 9.0 & 17.5 & 12,5 & 10 & 7.5 & \\
\hline \multicolumn{2}{|c|}{$\begin{array}{l}\text { Amplitude of the fluctuation of cardioc } \\
\text { cycle in middle stage }\end{array}$} & 0,03 & 0.02 & 0.01 & 0.11 & 0.02 & 0.03 & 0.02 & 0.02 & 0.01 & \\
\hline \multicolumn{2}{|c|}{ Aver. cardiac cycle prior the goal } & 0.47 & 0.41 & 0,35 & 0.42 & 0,40 & 0.41 & 0,38 & 0.41 & 0,40 & $0.41 \pm 0,03$ \\
\hline \multicolumn{2}{|c|}{$\begin{array}{l}\text { Amplifude of the fluctuation of cardiac } \\
\text { cycle prior the gool }\end{array}$} & 0.05 & 0.04 & 0.01 & 0.03 & 0.01 & 0.01 & 0.01 & 0.01 & 0.01 & \\
\hline \multicolumn{2}{|c|}{$\begin{array}{l}\text { Aver, cordiac cycle immediately after } \\
\text { the goal }\end{array}$} & 0.48 & 0.40 & 0.35 & 0.42 & 0.41 & 0.43 & 0.39 & 0.40 & 0.40 & $0.41 \pm 0.02$ \\
\hline \multicolumn{2}{|c|}{\begin{tabular}{|c|}
$\begin{array}{c}\text { Amplitude of the fluctuation of cordiac } \\
\text { cycle immediately ofter the gool }\end{array}$ \\
\end{tabular}} & 0.05 & 0.01 & 0.01 & 0.03 & 0.01 & 0.02 & 0.01 & 0.01 & 0.01 & \\
\hline \multicolumn{2}{|c|}{$\begin{array}{c}\text { Aver, cardiac cycleat 30seconds after } \\
\text { the goal }\end{array}$} & 0.54 & 0.42 & 0.40 & 0.41 & 0.43 & 0.49 & 0.44 & 0,50 & 0.46 & $0.45 \pm 0,04$ \\
\hline \multicolumn{2}{|c|}{$\begin{array}{l}\text { Amplifude of the fluctuation of cardioc } \\
\text { cycle at } 30 \text { seconds after the go al }\end{array}$} & 0.05 & 0.02 & 0.01 & 0.01 & 0.01 & 0.02 & 0.01 & 0.02 & 0.01 & \\
\hline \multicolumn{2}{|c|}{\begin{tabular}{|c|} 
Aver, cordiac cycle at one minute after \\
the goal
\end{tabular}} & 0.80 & 0.50 & 0.44 & 0.46 & 0.51 & 0.61 & 0.46 & 0.55 & 0.53 & $0.54 \pm 0.08$ \\
\hline \multicolumn{2}{|c|}{$\begin{array}{l}\text { Amplitude of the fluctuation of cordiac } \\
\text { cycle at one minute ofter the go al }\end{array}$} & 0.19 & 0.01 & 0.01 & 0.10 & 0.01 & 0.02 & 0.02 & 0.02 & 0.02 & \\
\hline \multicolumn{2}{|c|}{$\begin{array}{c}\text { Aver, cardiac cycle at two minutes offer } \\
\text { the goal }\end{array}$} & & & & & 0.59 & & 0.54 & & & \\
\hline \multicolumn{2}{|c|}{$\begin{array}{l}\begin{array}{c}\text { Amplitude of the fluctuation of cordioc } \\
\text { cycleat two minutes after the goal }\end{array} \\
\end{array}$} & & & & & 0.03 & & 0.03 & & & \\
\hline \multicolumn{2}{|c|}{ Record time } & 49.0 & 49.0 & 532 & 50.0 & 51.8 & 57.5 & 80.4 & 84.0 & 65.5 & \\
\hline \multicolumn{2}{|c|}{ Recovery time } & 58,0 & & & 70.5 & & 82.0 & & 99.0 & & \\
\hline
\end{tabular}


かも立位安静時において心搏週期の延長が著明な すのほど，急激に短縮している。この心搏週期の 急激な短樎については, 自由型と平泳の泳法によ る差は認められず，両者とす殆んどの者でほぼ直 線的に急短縮しているが，1 例のみに宇都山吕)や 野田 ${ }^{536)}$ の報告した陸上競技の疾走時にみられる ような心搏週期の急激な下降動摇を認めた。急下 降を示した 8 例の第 1 次下降終点では平均心搏週 期は $0.54 \pm 0.03$ 秒であった。第 2 次下降は水泳 開始より $11 \pm 3$ 秒まで続き，第 2 次下降終点での 平均心搏週期は $0.44 \pm 0.03$ 秒であった。

ii ）水泳中期の心搏週期の変動

9 例中 7 例で, 第 2 次下降終点到着後, 即ち タート開始より $11 \pm 3$ 秒以後, 心搏週期は 5〜15 秒位の間短縮せず，一定の水準 即ち $0.38 \sim 0.49$ 秒の心搏週期を保っている。この一定水準持続時 間を自由型と平泳の両者について比較すると, 自 由型の方が平泳よりる持続時間は短かく, 第 3 次 下降に早く移行寸る。第 3 次下降に移行してから す心搏週期は徐々に短縮し, 水泳開始から $45 \pm 13$ 秒で steady state に達する。自由型では steady state K達するのが平泳の場合よりる約 17 秒早い が, steady state での平均心搏週期の值には差は みとめられず， $0.39 \pm 0.07$ 秒であった。なお， $50 \mathrm{~m}$ 水泳での最小心搏週期の値は, 0.35 秒にまで 短縮しているものが 1 例だけあったが, 最小心搏 週期の平均值は $0.39 \pm 0.02$ 秒で，これ以下には 下らなかった。

iii） 水泳停止直前の心搏週期の变動

水泳停止直前の平均心搏週期は $0.41 \pm 0.03$ 秒 で, 水泳中期以後に比していくらか延長の傾向を 示している。

C $50 \mathrm{~m}$ 水泳停止後の心搏週期の変動

心搏週期は，水泳競技終了後 30 秒位までゆる やかに回復し，以後急速に回復の途をたどり，1 分後には $0.54 \pm 0.08$ 秒にまで回復している。9 例中 3 例では, スタート前の心搏週期の値に回復 するまで記録していないので不明であるが，4 例 では 60〜90秒でスタート前の心搏週期にまで回 復し, 残りの 2 例では回復に 2 分以上を要してい る。

水泳競技所要時間は, 自由型で平均 50.4 秒, 平泳では平均 71.9 秒であった。

\section{3. $100 \mathrm{~m}$ 水泳喼技時の心揞远期の变化}

(Fig. 2, Fig. 3, Table 3 参照)

A $100 \mathrm{~m}$ 水泳開始前の心搏週期の変動

水泳開始前の平均心搏週期の 値は $0.73 \pm 0.10$ 秒で，心搏週期の動摇振幅は $0.08 \pm 0.03$ 秒であ った。水泳開始前の平均心搏週期が 0.6 秒以上の 者では，心搏週期の呼吸性変動が著明であった。

B $100 \mathrm{~m}$ 水泳中の心搏週期の変動

i ） 水泳開始直後の心搏週期の変動

宇都山 ${ }^{374)}$ と野田 ${ }^{536)}$ は，陸上競技に拈いて疾走 開始と同時に，心搏週期の急激な下降動摇が出現 する者が多いと報告しているが，本実験において もこのような急激な下降動摇が，スタート後 0.5 $\sim 4.5$ 秒の間に 12 例中 5 例に出現した。 $100 \mathrm{~m}$ 水 泳に打けるスタート前後の心搏週期の変動経過は 次の 4 型に分類することができる。

第 1 型 : スタート後心搏週期はゆるやかに階段状

に短縮し，心搏週期の動摇は著明でないもの。

第 2 型 : 水泳開始前の心搏週期の值が 0.5 秒程度 に短縮しているにもかかわらず，スタート後心 搏週期の急激な下降動摇が現われるるの。

第 3 型 : スタート直後心搏週期が一時上年(延長)

し，1２回著明に動摇した後ゆるやかな下降 （短縮）に移行するすの。

第 4 型 : スタート前より心搏週期の動摇が著し

く,スタートの約 5 秒後にこの動摇が著しく減 少し,ゆるやかな下降に移行するるの。

以上 4 型とも，スタートより約 20 秒後には，心 搏週期は 10〜20 秒間一定水準を保ち，後再びゆ るやかな短縮に移行する。この一定水準における 心搏週期の值は $0.4 \sim 0.6$ 秒で，自由型では平泳 やバタフライに比して短縮が著明であった。

ii）水泳中期に打ける心搏週期の变動

スタート後䄪 20 秒で心搏週期が一定水準, 即 ち平均 $0.47 \pm 0.04$ 秒に達し, 以後 $10 \sim 20$ 秒間こ の水準を持続するが，心搏週期は再び徐々に短縮 し，78土17 秒後に steady state に達する。 steady state での平均心搏週期の值は $0.40 \pm 0.02$ 秒で, それが出現する時間は自由型が最も早く, 次いで 背泳, 平泳, ハタフライの順となっている。男子 と女子について， steady state に達するまでの時 間を比較すると,女子では53〜55 秒で全員 steady state に達するが，男子では执そく，60 秒以上か 


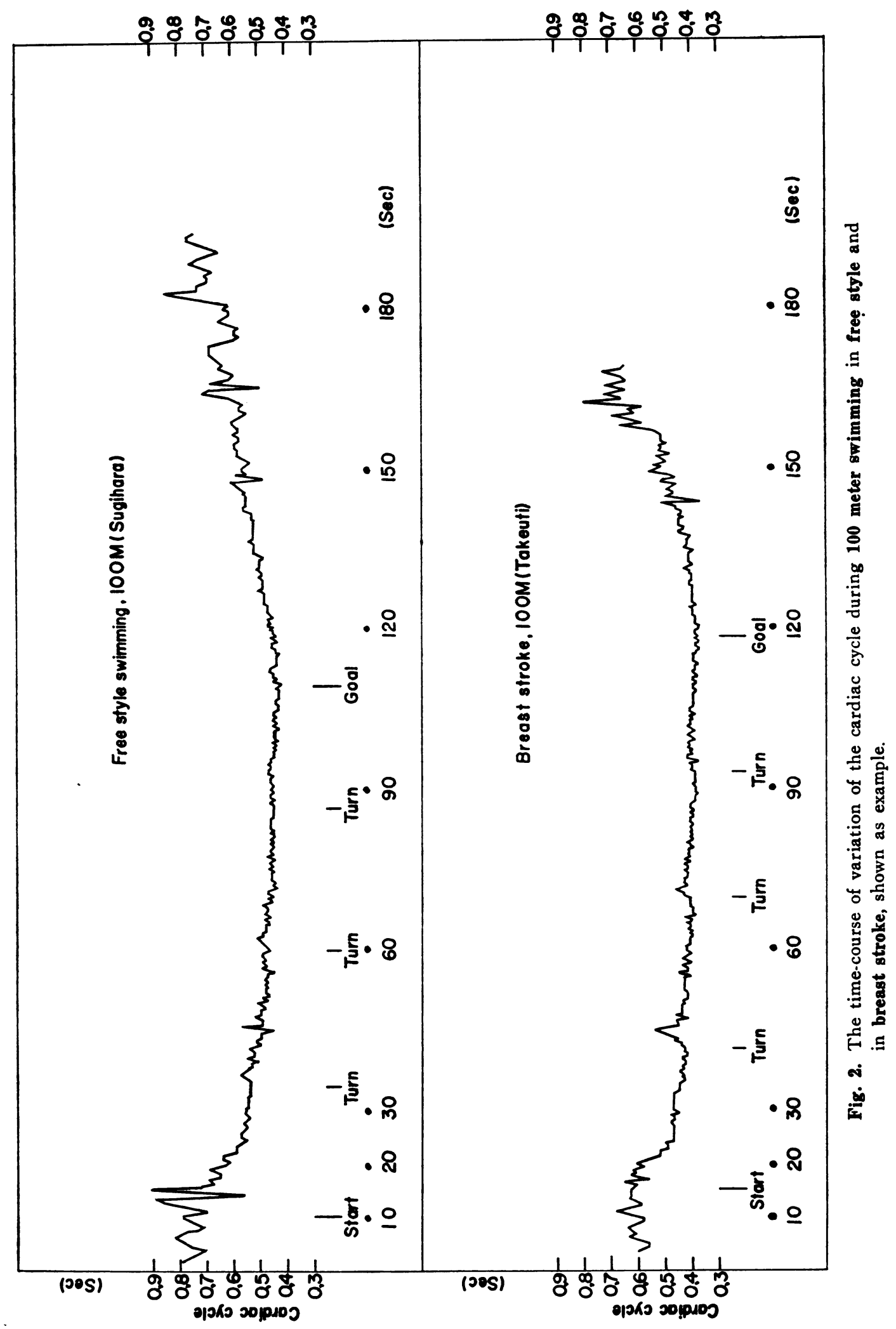




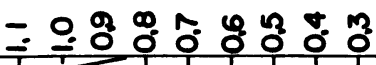

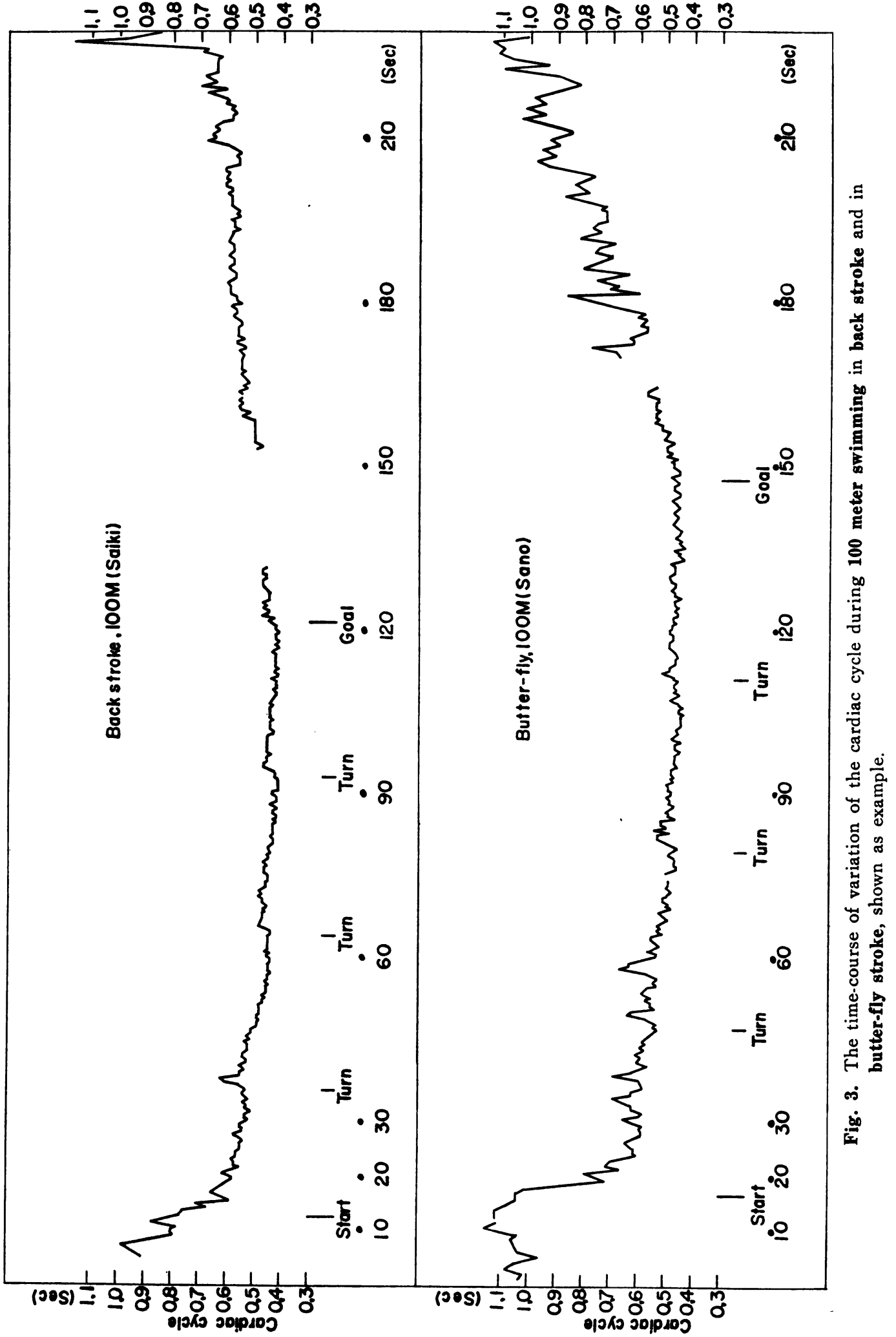


Table 3. Experimental data for 100 meter swimming in each style or stroke.

\begin{tabular}{|c|c|c|c|c|c|c|c|c|c|c|c|c|c|}
\hline \multirow[b]{2}{*}{ Unit(Sec) } & \multicolumn{5}{|c|}{ Free style } & \multicolumn{3}{|c|}{ Breost stroke. } & \multicolumn{3}{|c|}{ Bock stroke } & \multirow{2}{*}{\begin{tabular}{|l|} 
But- \\
ter-fly \\
Sono \\
\end{tabular}} & \multirow[b]{2}{*}{$\begin{array}{l}\text { Limit of rell - } \\
\text { ancel(a-0.05) }\end{array}$} \\
\hline & $\begin{array}{l}\text { Sugi- } \\
\text { hora } \\
\text { m }\end{array}$ & $\begin{array}{l}\text { Full- } \\
\text { mura }\end{array}$ & Nodo & Ötuko & $\begin{array}{c}\text { Koho- } \\
\text { ro }\end{array}$ & Inove & $\begin{array}{c}\text { Take- } \\
\text { uti }\end{array}$ & Akito & Abe 5 & Soiki 18 & Ishiyo & & \\
\hline Aver,cardioc cycle bofore start & 0.750 & 0.57 & $0.57 \mathrm{C}$ & 0.56 & 0.56 & 0.74 & 0.61 & 0.77 & $0.87 \mathrm{C}$ & $0.96 \mathrm{c}$ & 0.701. & $1.04 a$ & $0.73 \pm 0.10$ \\
\hline $\begin{array}{c}\text { Amplitude of the fluctuation of cardioc } \\
\text { cycle before start }\end{array}$ & 0.130 & 0.02 & 0.04 & 0.04 & 0.06 & 0.06 & 0.07 & $0.15 \mathrm{C}$ & 0,08 & 0.14 & $0.05 \mathrm{C}$ & 0.090 & $0,08 \pm 0,03$ \\
\hline $\begin{array}{l}\text { Terminal point of ropid shortening of } \\
\text { cordloc cycle inmediotely offer stort }\end{array}$ & & 0.48 & 0.47 & 0,50 & & & & 0.69 & 0,69 & 0.66 & & 0.710 & $0.61 \pm 0.08$ \\
\hline \multirow{4}{*}{$\begin{array}{l}\text { Rapid fluctuation of } \\
\text { cordiac cycle during } \\
\text { swimming }\end{array}$} & 0.35 & & 0.19 & & & & & & 0.10 & 0.13 & & $0.13 \mid 0$ & $0.16 \pm 0.21$ \\
\hline & 0.73 & & 0.50 & & & & & & 0.66 & $|0,64|$ & & 0.700 & $0.63 \pm 0.08$ \\
\hline & 4,50 & & 0.50 & & & & & & 2.50 & 1.50 & & 2.50 & \\
\hline & 5.00 & & 4,00 & & & & & & 4.00 & 3.00 & & 5.003 & $3,80 \pm 1.00$ \\
\hline $\begin{array}{l}\text { Aver, cardioc cycle immedilotely ofter storn } \\
\text { (not ropld fluctuotion) }\end{array}$ & & 0.50 & & & 0.51 & & & 0.66 & & & & & \\
\hline \multirow{3}{*}{$\begin{array}{l}\text { Terminal point of shortening } \\
\text { of the second stage }\end{array}$} & $0.55 \mathrm{C}$ & $0.41 C$ & $0.41 c$ & 0.41 & 0.43 & 0.56 & 0.440 & 0.43 & 0.49 & 0.520 & 0.42 & $0.54 \mid c$ & $0.47 \pm 0.04$ \\
\hline & 21.01 & $17.0 \mid 1$ & 16.02 & 26.0 & 21.0 & 13.0 & 20.01 & 18,0 & $18.0 \mid 1$ & $18,\left.0\right|^{2}$ & 230 & $30.0 \mid 2$ & $20.0 \pm 3.00$ \\
\hline & 0.0210 & $0.01 C$ & 0.02 & 0.01 & 0.02 & 0.02 & 0.01 & 0.02 & 0.01 & 0.02 & 0.01 & 0.02 & \\
\hline \multirow{2}{*}{$\begin{array}{l}\text { Steady state of cardiac } \\
\text { cycle }\end{array}$} & $0.45 \mathrm{C}$ & 0.36 & $0.37 C$ & 0.39 & 0.40 & & 0.40 & & 0.45 & 0.420 & $0.37 c$ & $\left.0.46\right|^{0}$ & $0.41 \pm 0.03$ \\
\hline & 86.077 & 72.0 & 52.0 & 53.0 & 550 & & 63.5 & & 60.5 & $95.0 \varepsilon$ & $82.0 \mid 1$ & 1157 & $73.0 \pm 15.0$ \\
\hline $\begin{array}{l}\text { Amplitude of the fluctuation of cordiac } \\
\text { cycle in the steady state }\end{array}$ & $0.01 c$ & 0.01 & 0.02 & 0.01 & 0.02 & & 0.01 & & 0.01 & 0.01 & $0.01 \mathrm{c}$ & $0.02 \mid$ & \\
\hline Minimum condloc cycle during swimming & $0.43 c$ & 0.34 & $0.34 \mathrm{C}$ & 0.58 & 0.37 & 0.41 & 0.38 & 0.36 & 0.43 & $0.41 C$ & $0.34 \mathrm{C}$ & $0.44 \mid c$ & $0,40 \pm 0.01$ \\
\hline \multirow{3}{*}{$\begin{array}{l}\text { Aver.minimum cardioc cycte } \\
\text { during swimming }\end{array}$} & 0.45 & 0.36 & 0.37 & 0.39 & 0.38 & 0.42 & 0.390 & 0.37 & 0.44 & $0.41 c$ & 0.370 & 0.450 & $0.40 \pm 0.02$ \\
\hline & 86.0 & 72.0 & $52,0 \mid$ & 53.0 & 58.0 & 96,0 & 72.0 & 102 & 87.0 & 78.0 & 82.01 & 11150 & $78.0 \pm 17.0$ \\
\hline & $7.50 \mid 1$ & |8.2 | & 17.0 & 59.7 & 5.00 & 4.00 & 7.50 & 11.0 & 4.20 & 5.50 & 39.0 & 5.50 & \\
\hline $\begin{array}{l}\text { Amplitude of the fluctuation of cordioc } \\
\text { cycle in middle stoge }\end{array}$ & 0.01 & 0.01 & 0.02 & 0.01 & 0.02 & 0.01 & 0.01 & 0.02 & 0.02 & 0.010 & 0.02 & 0.04 & \\
\hline Aver, cardiac cycle prior the goal & 0.44 & 0.35 & 0.38 & 0.39 & 0.41 & 0.42 & 0.39 & 0.37 & 0.44 & 0.42 & $0.36 \mathrm{C}$ & $0.46 c$ & $0.40 \pm 0.02$ \\
\hline $\begin{array}{c}\begin{array}{c}\text { Amplitude of the fluctuation of cordioc } \\
\text { cycle priar the goal }\end{array} \\
\end{array}$ & 0.01 & 0.01 & 0.02 & 0.01 & 0.01 & 0.01 & 0.01 & 0.01 & 0.01 & $0.01 \mathrm{c}$ & 0.02 & 0.02 & \\
\hline $\begin{array}{l}\text { Awercordioc cycle immediotely after } \\
\text { the gool }\end{array}$ & 0.45 & & 0.37 & 0.39 & 0.41 & 0.42 & 0.39 & 0.37 & 0.43 & 0.43 & $0.36 \mathrm{c}$ & 0.460 & $0.41 \pm 0.02$ \\
\hline $\begin{array}{c}\text { Amplitude of the fluctuation of cordice } \\
\text { cycle immediately after the goal }\end{array}$ & 0.02 & & 0.01 & 0.01 & 0.04 & 0.01 & 0.01 & 0.01 & 0.01 & 0.02 & $0.01 \mathrm{k}$ & 0.03 & \\
\hline \begin{tabular}{|c|}
$\begin{array}{c}\text { Aver.cordioc cycle of } 30 \text { seconds ofter } \\
\text { the gool }\end{array}$ \\
\end{tabular} & 0.52 & 0.41 & 0.45 & 0.46 & 0.54 & 0.52 & 0.49 & 0.47 & 0,54 & & 0.41 & 0.610 & $049 \pm 0.04$ \\
\hline $\begin{array}{l}\text { Amplitude of the fluctuotion of cordioc } \\
\text { cycle ot } 30 \text { seconds ofter the gool }\end{array}$ & 0.01 & 0.01 & 0.02 & 0.01 & 0.02 & 0.01 & 0.05 & 0.04 & 0.04 & & $0.01 k$ & 0.04 & \\
\hline $\begin{array}{l}\text { Aver.cordioc cycle of one minute after } \\
\text { the gool }\end{array}$ & 0.63 & 0.45 & 0.70 & 0.58 & & 0.57 & & 0.87 & & 0.58 & $0.50 \mathrm{C}$ & 0.930 & $0.65 \pm 0.12$ \\
\hline \begin{tabular}{|l|}
$\begin{array}{c}\text { Amplthude of the fluctuotion of cordioc } \\
\text { cycle of one minute ofter the gool }\end{array}$ \\
\end{tabular} & 0.04 & 0.02 & 0,06 & 0.05 & & 0.04 & & 0.12 & & 0.02 & $0.01 \mathrm{c}$ & 0.06 & \\
\hline $\begin{array}{l}\text { Aver.cardioc cycle oft two minutes ofter } \\
\text { the gool }\end{array}$ & & & & & & & & & & & 0.59 & & \\
\hline $\begin{array}{l}\text { Amplitude of the fluctuation of cardioc } \\
\text { eyde of twominutes offer the goal }\end{array}$ & & & & & & & & & & & 0.04 & & \\
\hline Record time & 98.6 & 90.2 & 87.8 & 112.7 & 129 & 1028 & 1041 & 116.2 & 91.2 & III.4 & 121.8 & 129.5 & \\
\hline Recovery Itrme & 73.0 & 93.0 & 51.0 & 54.0 & 340 & 94.0 & 40.0 & $580 \mid$ & & 1113 & & 74,0 & \\
\hline
\end{tabular}


かっている。しかし, 心搏週期の短縮度には有意 差は認められない。水泳中の心搏週期の微細動摇 は, 自由型で最も小さく，かつその動摇週期す短 かいが, 平泳, 背泳に次いでバタフライでは最も 大きく，動摇週期 6長い。水泳中の最小心搏週期 の値が 0.34 秒とい5者が 3 例あったが, 平均最小 心搏週期は $0.40 \pm 0.02$ 秒であった。このように steady state に達した後は,このレベルのままで ゴールに達するが, 変動経過図では全例に, ター ソの後若干の心搏週期の延長が認められる。但し コールに近つくに従ってこの延長の程度が少なく なる傾向がある。

\section{iii）水泳停止直前の心搏週期の変動}

$50 \mathrm{~m}$ 水泳の場合には, ゴール前に心搏週期がや や延長する傾向があったが, $100 \mathrm{~m}$ の場合は, こ のようなことはなく, 停止直前における平均心搏 週期の值は $0.40 \pm 0.02$ 秒であった。

C $100 \mathrm{~m}$ 水泳停止後の心搏週期の変動 水泳停止後, 初期の回復が現われるまでの時間 は一定せず, 平泳, 背泳, バタフライでは停止直 後から回復が始まるが, 自由型ではやや遅れる傾 向にあり，ゴール到達後約 8 秒で回復に入る。し かし水泳停止直後の平均心搏週期 の值は $0.41 \pm$ 0.02 秒で, 全例に括いて steady state での值より ○0. 01 秒延長している。水泳停止後 30 秒では, 平均心搏週期は $0.49 \pm 0.04$ 秒, 1 分後には $0.65 \pm$ 0.12 秒と急速に回復に向かい, 1 例を除けば殆ん どすへて， 1 分前後で水泳開始前の 平均心搏週期 の值にまで回復している。な打水泳停止後 30 秒 での心搏週期の動摇の振幅は, 平泳, 背泳, バタ フライではやや大きいが, 自由型では最も小さい。 しかし 1 分後になると, 自由型でも他の泳法と同 様に, 心搏週期の動摇は著明になり, 回復が進む にしたがって心搏週期の動摇の振幅す大きくなっ てくる。

\section{$4400 \mathrm{~m}$ 水泳新技時の心诚期の变化}

(Fig. 4, Fig. 5, Table 4 参照)

\section{A $400 \mathrm{~m}$ 水泳開始前の心搏週期の変動}

被検者 7 例の 5 万, 水泳開始前の心搏週期の値 が 0.5 秒前後の者が 2 例で, 4 例は $0.6 \sim 0.8$ 秒, 他の 1 例は徐脈の傾向にあり, 水泳開始前の平均 心搏週期の値は $0.65 \pm 0.14$ 秒, 心搏週期の動摇 の振幅は $0.04 \pm 0.02$ 秒であった。 $50 \mathrm{~m}, 100 \mathrm{~m}$ の
場合と同様に, スタート前の平均心搏週期の值が 0.6 秒以上の者では著明な呼吸性動摇を示すが, 0.5 秒程度の者では動摇はあまり著明でない。

B $400 \mathrm{~m}$ 水泳中の心搏週期の変動

i ) 水泳開始直後の心搏週期の变動

水泳開始々同時に心搏週期の短縮が始まるが, 開始直後急激に短縮するすのは 3 例で, 他の 4 例 では徐々に短縮している。しかるこの3例の5ち 1 例では急激な下降動摇が認められた。この急短樎 の 3 例では, 水泳開始と同時に心搏週期は急激に 直線的に一度下降し, 次いで第 2 次下降に移行し た後一定水準を保ち, 更に第 3 次下降に移行する。 他の 4 例では, 心搏週期は水泳開始後階段状に短 縮し, 以後第 2 次下降, 第 3 次下降に移行する。 前記急短縮の 3 例は全部国体選手であり, 階段状 下降の 4 例は德島大学医学部の選手であった。急 激な下降動摇を示した 1 例での心搏週期の動摇の 最大振幅は 0.07 秒で, 出現時間は水泳開始の 2.5 秒後で，その持続時間は 2.5 秒であった。

ii）水泳中の心搏週期の変動

第 2 次下降終点の出現は水泳開始後 $22 \pm 11$ 秒 で,このときの平均心搏週期の值は $0.44 \pm 0.04$ 秒 となり, 以後 $10 \sim 15$ 秒の一定水準を保った後第 3 次下降に移り, 水泳開始後 76〜390秒で steady state に達する。 steady state の出現と泳いだ距離 の関係を見ると, 早いものでは $70 \mathrm{~m}$ 附近で, 遅い ものでは $250 \mathrm{~m}$ あたりから現われている。このと きの平均心搏週期の値は $0.41 \pm 0.04$ 秒であった。 $400 \mathrm{~m}$ 水泳でも $100 \mathrm{~m}$ 水泳の場合と同様に, タ一 ン時に心搏週期の一時延長が認められた。又, 国 体選手と医学部選手を対比すると, steady state 達するまでの時間に差は認められなかったが， steady state での平均心搏週期の値は医学部選手 で 0.35〜0.39 秒, 国体選手で $0.41 \sim 0.49$ 秒と著 明な差がある。又, 国体選手の水泳中の最小心搏 週期の値は殆んどすべて 0.34 秒以上で $0.38 〜$ 0.48 秒, 医学部選手では $0.32 \sim 0.38$ 秒であり, 心搏週期の短縮の程度は医学部選手の方が強い傾 向にあった。水泳中期での心搏週期の動摇は少な く, 平均動摇振幅は $0.02 \pm 0.01$ 秒で,一般に国 体選手の方が動摇は大きい。

iii）水泳停止直前の心搏週期の変動

水泳停止直前における心搏週期の変動は, 水泳 


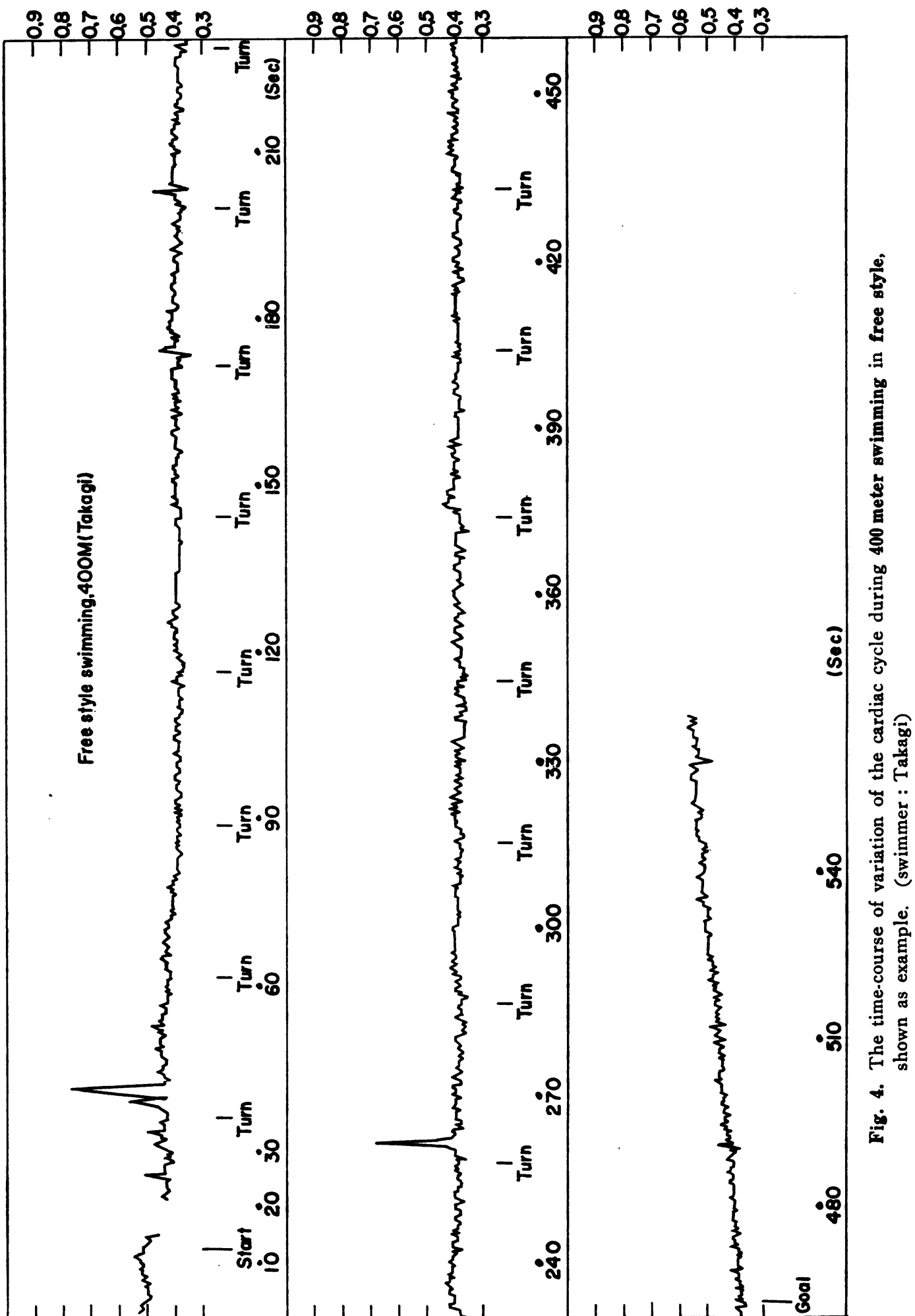




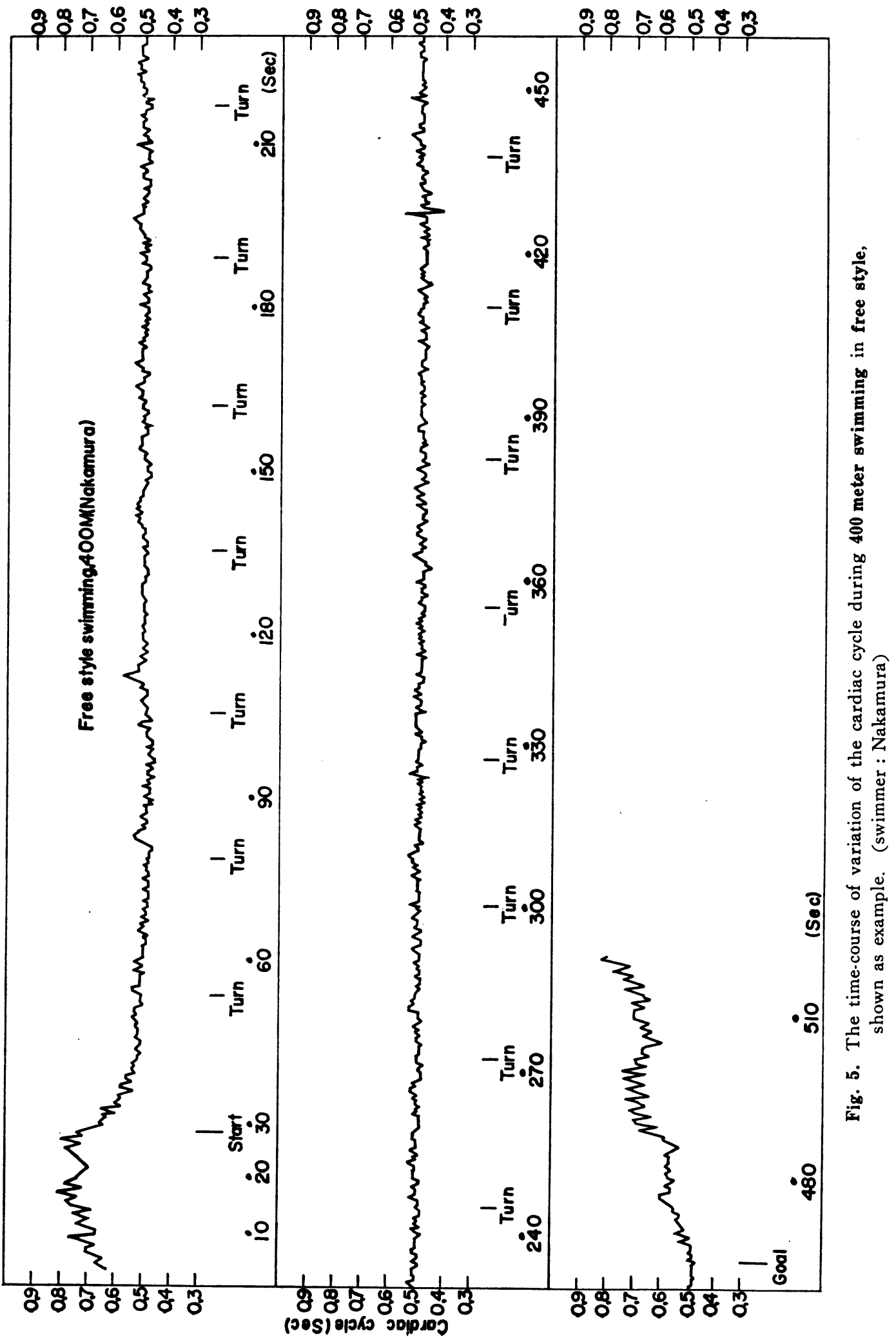


Table 4. Experimental data for $\mathbf{4 0 0}$ meter swimming in free style for group $A$ and $B$. Group A : Champions of the Japan National Athletic Meeting.

Group B : Swimming club members of the medical school.

\begin{tabular}{|c|c|c|c|c|c|c|c|c|c|}
\hline \multirow{2}{*}{\multicolumn{2}{|c|}{ Unit(Sec) Subject }} & \multicolumn{2}{|c|}{ Group A } & \multirow{2}{*}{ A } & \multicolumn{4}{|c|}{ Group $B$} & \multirow[b]{2}{*}{\begin{tabular}{|l|l|} 
Limit of ret: \\
oncela-0.055
\end{tabular}} \\
\hline & & \begin{tabular}{l|l}
$\begin{array}{l}\text { Kuro- } \\
\text { moto }\end{array}$ & $n$ \\
\end{tabular} & $\begin{array}{l}\text { Naka- } s \\
\text { muro }\end{array}$ & & Ormuro & \begin{tabular}{|l|l|}
$\begin{array}{l}\text { Ura- } \\
\text { gami }\end{array}$ \\
\end{tabular} & $\begin{array}{lll}\text { Hora- } \\
\text { do- }\end{array}$ & Tako- & \\
\hline \multicolumn{2}{|c|}{ Aver, cardlac cycle before start } & 0.650 & 0.760 & 0.92 & 0.61 & 0.48 & 0.62 & 0.53 & $0.65 \pm 0.14$ \\
\hline \multicolumn{2}{|c|}{$\begin{array}{l}\text { Amplitude of the fluctuation of cardioc } \\
\text { cycle before start }\end{array}$} & 0.030 & 0.060 & 0.09 & 0.03 & 0.040 & 0.03 & 0.02 & $0.04 \pm 0.02$ \\
\hline \multicolumn{2}{|c|}{$\begin{array}{l}\text { Terminal point of rapid shortening of } \\
\text { cordiac cycle immediately after the stort }\end{array}$} & 0.540 & 0.65 & 0,53 & & & 0.55 & & $0.57 \pm 0.09$ \\
\hline \multirow{4}{*}{$\begin{array}{l}\text { Rapid fluctuotion of } \\
\text { cordiac cycle during } \\
\text { swimming }\end{array}$} & $\begin{array}{c}\text { Greatest } \\
\text { omplifude }\end{array}$ & & 0.07 & & & & & & \\
\hline & \begin{tabular}{|l|} 
Level of \\
amplitude \\
\end{tabular} & & 0.62 & & & & & & \\
\hline & \begin{tabular}{|l|} 
Time of \\
oppearance
\end{tabular} & & 2.50 & & & & & & \\
\hline & \begin{tabular}{|l|}
$\begin{array}{c}\text { Time of } \\
\text { continuation }\end{array}$ \\
\end{tabular} & & 2,50 & & & & & & \\
\hline \multirow{3}{*}{$\begin{array}{l}\text { Terminal point of } \\
\text { shortening of the } \\
\text { second stage }\end{array}$} & \begin{tabular}{|c|c|}
$\begin{array}{c}\text { Aver, cordloc } \\
\text { cycle }\end{array}$ & C \\
\end{tabular} & $0.44 C$ & $0.51 \mathrm{c}$ & 0.48 & 0.49 & 0.39 & & 0.43 & $0.44 \pm 0.04$ \\
\hline & \begin{tabular}{|l|l|}
$\begin{array}{l}\text { Time of of } \\
\text { oppearance }\end{array}$ & 1 \\
\end{tabular} & $12.0 \quad 2$ & $23.0]^{3}$ & 33.0 & 29.0 & 22.0 & & 10.0 & $21.5 \pm 9.5$ \\
\hline & \begin{tabular}{|c|c|c|c|c|c|c|c|}
$\begin{array}{c}\text { Amplitude of } \\
\text { fluctuation }\end{array}$ \\
\end{tabular} & 0.025 & 0.02 & 0.02 & 0.01 & 0.01 & & 0.01 & \\
\hline \multirow{2}{*}{$\begin{array}{l}\text { Steady state of } \\
\text { cardiac cycle }\end{array}$} & \begin{tabular}{|c|c|}
$\begin{array}{c}\text { Aver, condioc } \\
\text { cycle }\end{array}$ & C \\
\end{tabular} & $0.41 c$ & 0.490 & 0.44 & $|0.38|$ & $0,35 \mid c$ & 0.39 & 0.39 & $0.41 \pm 0.04$ \\
\hline & \begin{tabular}{|l|l|} 
Time of of \\
oppearance
\end{tabular} & 172 & $\left.240\right|^{2}$ & 201 & 390 & 76 & 190 & 206 & $210 \pm 88$ \\
\hline \multicolumn{2}{|c|}{\begin{tabular}{|c|}
$\begin{array}{c}\text { Amplitude of the fluctuation of cordiac } \\
\text { cycle in the steody state }\end{array}$ \\
\end{tabular}} & 0.02 & $0.02 \mathrm{C}$ & 0.01 & 0.01 & 0.01 & 0.01 & 0.02 & \\
\hline \multicolumn{2}{|c|}{ Minimum cardioc cycle during swimming } & 0.36 & 0.41 & 0.40 & 0.34 & 0.32 & 0.36 & 0.34 & $0.36 \pm 0.03$ \\
\hline \multirow{3}{*}{$\begin{array}{l}\text { Aver, minimum cardiac } \\
\text { cycle during swimming }\end{array}$} & Cardioc cycie & $0.38 \mathrm{C}$ & $0.48 c$ & 0.43 & 0.37 & 0.34 & 0.38 & 0.38 & $0.39 \pm 0.04$ \\
\hline & \begin{tabular}{|l|}
$\begin{array}{l}\text { Time of } \\
\text { oppeorance }\end{array}$ \\
\end{tabular} & 64 & 65 & 270 & 420 & 147 & 359 & 268 & $228 \pm 130$ \\
\hline & \begin{tabular}{|l|}
$\begin{array}{l}\text { Time of } \\
\text { continuotion }\end{array}$ \\
\end{tabular} & 12.0 & 7.0 & 11.0 & 164 & 333 & 75,8 & 10.5 & \\
\hline \multicolumn{2}{|c|}{\begin{tabular}{|l|}
$\begin{array}{c}\text { Amplitude of the fluctuotion of cordiac } \\
\text { cycle in middle stage }\end{array}$ \\
\end{tabular}} & $|0.04|$ & 0.02 & 0.03 & 0.01 & 0.01 & 0.01 & $0.02 \mid C$ & $0.02 \pm 0.01$ \\
\hline \multicolumn{2}{|c|}{ Aver, cardiac cycle prior the gool } & 0.41 & 0.48 & 0.45 & 0.37 & 0.36 & 0.38 & 0.38 & $0.40 \pm 0.04$ \\
\hline \multicolumn{2}{|c|}{\begin{tabular}{|c|}
$\begin{array}{c}\text { Amplifude of the fluctuation of cardiac } \\
\text { cycle prior the goal }\end{array}$ \\
\end{tabular}} & 0.01 & 0.01 & 0.01 & 0.01 & 0.02 & 0.01 & 0.03 & \\
\hline \multicolumn{2}{|c|}{$\begin{array}{c}\text { Aver,cardiac cycle immediately after } \\
\text { the gooll }\end{array}$} & 0.44 & 0.48 & 0.47 & 0.37 & $0,36 \mid C$ & 0.38 & 0.38 & $0.40 \pm 0.04$ \\
\hline \multicolumn{2}{|c|}{$\begin{array}{l}\text { Amplitude of the fluctuation of cardioc } \\
\text { cycle immediately offer the gool }\end{array}$} & 0.01 & 0.01 & 0.01 & 0.01 & 0.02 & 0.02 & 0.04 & \\
\hline \multicolumn{2}{|c|}{$\begin{array}{c}\text { Aver.cardiac cycle at } 30 \text { seconds after } \\
\text { the gool }\end{array}$} & 0.54 & 0,68 & 0.78 & 0.42 & $0.41 \mathrm{C}$ & 0.42 & 0.43 & $0.53 \pm 0.14$ \\
\hline \multicolumn{2}{|c|}{\begin{tabular}{|} 
Amplitude of the fluctuation of cordiac \\
cycle of 30 seconds after the go al \\
\end{tabular}} & 0.03 & 0.08 & 0.09 & 0.02 & 0.02 & 0.01 & 0.02 & \\
\hline \multicolumn{2}{|c|}{$\begin{array}{l}\text { Aver, cordiac cycle at one minute after } \\
\text { the goal }\end{array}$} & 0.78 & & .92 & 0.48 & 0.42 & 0.53 & 0.48 & $0.60 \pm 0.21$ \\
\hline \multicolumn{2}{|c|}{$\begin{array}{l}\text { Amplifude of the fluctuotion of cardiac } \\
\text { cycle ot one minute ofter the goal }\end{array}$} & 0.05 & & 0.12 & 0.01 & 0.02 & 0.02 & 0.03 & \\
\hline \multicolumn{2}{|c|}{$\begin{array}{l}\text { Aver. cordiac cycle of two minutes ofter } \\
\text { the gool }\end{array}$} & & & & 0.55 & & & & \\
\hline \multicolumn{2}{|c|}{\begin{tabular}{|c|} 
Amplitude of the fluctuation of cordioc| \\
cycle ot two minutes after the gool \\
\end{tabular}} & & & & 0.01 & & & & \\
\hline \multicolumn{2}{|c|}{ Record time } & 385.4 & 4 & 443.2 & 584,3 & 4803 & 4348 & 4405 & \\
\hline Recovery fi & lime & 35.0 & 55.0 & 52.0 & & & 83.0 & & \\
\hline
\end{tabular}


中期とあまり変わりがなく, 小さい動摇をくり返 しつつゴールに達し, 水泳停止後数秒で回復に向 か5。

C $400 \mathrm{~m}$ 水泳停止後の心搏週期の变動

水泳停止直後の平均心搏週期の值は $0.40 \pm 0.04$ 秒で, 医学部の水泳選手では水泳停止後数秒間,

停止直後の心搏週期の值を持続し, 䄪 $2.0 \sim 5.5$ 秒 後に初期回復飞入る。一方, 国体選手は水泳停止 直後の心搏週期の值が $0.44 \sim 0.48$ 秒で, 停止直前 よりやや延長し, 従って停止と同時か, 遅くとも 0.5 秒後には回復に向っている。水泳停止後 30 秒 で平均心搏週期は $0.53 \pm 0.14$ 秒まで急速に回復 するが，国体選手では回復が非常に早く，1 分以 内には全員が水泳開始前の平均心搏週期の值にも どっている。これに反し, 医学部の選手では回復 の早い例で 83 秒, 遅い例では 2 分経過しても水 泳開始前の状態に回復していない。

\section{考察}

\section{1. 水泳中の心捕週期の变䑤経過}

Fig. 1 5 の経過図と Table 2〜4 から水泳中の 心搏週期の変動経過を 3 つの距離 $(50 \mathrm{~m}, 100 \mathrm{~m}$, $400 \mathrm{~m}$ ) について比較すると, スタ一ト直後の急激 な下降動摇の出現率は, $100 \mathrm{~m}$ 水泳の場合が $50 \mathrm{~m}$, $400 \mathrm{~m}$ 水泳のときよりる大である。これは $100 \mathrm{~m}$ 水 泳の場合に, $50 \mathrm{~m}, 400 \mathrm{~m}$ 水泳に比へて水泳開始前 の平均心搏週期の值が大であるために, 宇都山吕4) や野田 ${ }^{5) 6)}$ が述へた如く, 運動開始直後運動筋から の反射による心臓抑制神経の抑制の解除が一層強 く働いて,すみやかに心搏週期の急下降(急短縮), すなわち心搏数增加が起り, 分時搏出量が増加す る。次いで大動脈反射や頸動脈洞反射などの心臓 反射によって心搏週期の延長が起るために，心搏 週期は大きく動摇し，これが心搏週期の下降動摇 の出現を招来したのであろろ。50m 水泳では, 100 $\mathrm{m}, 400 \mathrm{~m}$ 水泳より第 2 次下降終点の出現時期が 早いが，これは $100 \mathrm{~m}$ 水泳に比へてて医離が短かい ためにスタートして直にスパートをかけ, 強い負 荷が加わる結果, 運動初期の心搏週期の短縮が著 明に現われたのであろ5。以上のよ5に初期動 摇, 第 2 次下降終点の出現時期などには泳ぐ距離 による差が認められたが, 平均最小心搏週期, 回復 経過などには，このような距離による差が認めら れなかった。これは水泳に拈いては，50m 水泳の ように距離が短かくてもピッチ数が多いため, 心 搏週期の初期短縮が急であり，しかる競技時間が 約 50 秒も要したために, $100 \mathrm{~m}, 400 \mathrm{~m}$ 水泳と同し 程度まで心搏週期が短縮したものと考える。

次に, 宇都山(4) と野田 ${ }^{5}$ の報告した陸上競技の中 長距離疾走時の心搏週期の変動経過 と比較する 々, 運動初期の心搏週期の階段状短縮とか, 第 2 次下降, 第 3 次下降, steady state の出現, およ び経過中の微細動摇の出現などは, 心搏週期の短 縮度や出現時期にいくらかの差はあるるのの, 陸 上競技の中長距離疾走時における経過と非常によ く似ている。これは水泳に拈いては, 距離は短か いが水の抵抗, 浮力, 水圧など運動負荷が大き く, 更に呼吸運動の制限に加えて, 運動所要時間 が長いことなどの諸因により，呼吸循環機能への 影響が陸上競技の中長距離疾走におけると同じ程 度にまで加わったためと考える。

\section{2. 水泳開始直後の心搏週期の短絈}

一般に運動開始と同時に心搏週期が短縮するこ とはよく知られているが，この起因について，宇 都山 $^{334)}$ 々野田 ${ }^{536)}$ は最初運動筋からの直接反射で 心臟抑制神経の抑制解除が起り, 更に促進神経の 興奮やアドレナリンの内分泌で心搏週期の短縮が 起ると報告しているが，著者の実験でる水泳開始 と同時に心搏週期の短縮が起り，3 距離の5ちで は $50 \mathrm{~m}$ 水泳の場合に最も強く短縮し, 次いで 100 $\mathrm{m}, 400 \mathrm{~m}$ 水泳の順になっている。これはスター 卜時の運動の強さ，すなわち負荷の大きさやトレ ーニング効果の影響と考える。

\section{3. 水泳開始直後の心拥期の下降動搯}

宇都山(3)4) と野田 ${ }^{536)}$ は陸上での疾走時には, ス タート前の平均心搏週期の値が 0.6 秒以上の例で は, スタート直後の心搏週期が $2 \sim 3$ 回大きく動 摇する例が多いと報告しているが, $50 \mathrm{~m}$ 水泳では 1 例, $100 \mathrm{~m}$ 水泳では 5 例, $400 \mathrm{~m}$ 水泳では 1 例の 動摇しか出現しなかった。このように水泳では,ス タート前に心搏週期が延長しているにすかかわら ず, 下降動摇の出現率が低いのは, 水泳中は激し い運動をするとは云え, 先に実験方法の項で述へ たと扣り，スタート方法が水中での立位からのス タートであり，陸上競技のときほどスタート時の 運動が激しくなかったために, 自律神経緊張のハ 
ランスが大きく動摇しないまま心搏週期が短縮 し，第 2 次下降終点に達したすのと考兄る。しか し実験成績の項に述べた $100 \mathrm{~m}$ 水泳の第 2 型の場 合には，水泳開始前の心搏週期が 0.57 秒と割合 短縮しているにるかかわらず，急激な下降動摇が あり，しかる心搏週期の動摇の振幅水準は 0.5 秒 で，陸上競技 (疾走) 時に宇都山采 ${ }^{8}$ は疾走開始直 後の急激な下降は運動筋から反射的に心炡抑制神 䄳の抑制の解除が強くおこるためで，これによる 心搏週期の短縮は 0.5 秒までであろろと述べてい るが，この値と一致しているところをみると，水 泳開始時の負荷の強さだけでなく個人差も, 心搏 週期の下降動摇の要因の一部をなすのではなかろ らかと考える。また $100 \mathrm{~m}$ 水泳の第 3 型では, 止 息の状態でスタートしたために心搏週期の延長が 扣こり，その後運動筋からの反射による心搏週期 の短縮や, スタート直後の心搏週期の延長に対し て頸動脈洞反射, 大動脈反射等の心臟反射による 心搏週期の短縮が起り，自律神経系のバランスが くずれて心搏週期の值が動摇したのであろう。な 技第 4 型については, その後心疾患を認めたので， このような特異な波型を示したのであろう。

\section{4. 初期下降後の一定水準}

$50 \mathrm{~m}, 100 \mathrm{~m}, 400 \mathrm{~m}$ 水泳の全例とも，心搏䓢期 の第2 次下降終点，すなわち $50 \mathrm{~m}$ 水泳ではスタ 一ト後 $11 \pm 3$ 秒, $100 \mathrm{~m}$ 水泳では $20 \pm 3$ 秒, $400 \mathrm{~m}$ 水泳では $22 \pm 11$ 秒後からは, 心搏週期は余り短 縮せず，一定の水準を保ちつつ約 10〜20 秒間経 過するが, 更にその後再び第 3 次下降に移行する。 この一定水準は, 初期の心搏週期短縮, すなわち 運動筋からの反射による心荿抑制神経の抑制の解 除によって起った循環機能の乱れが，これに続い て起る心臓反射と促進神経の興奮によって自律神 経緊張のバランスが保たれることにより, 循環系 のアンバランスが調整される一方, 同程度の負荷 運動の持続によって，心搏週期はしばらく急激な 短縮 す延長す起らず，一定水準に維持されるるの と考える。しかし更に運動が続くために生じた筋 の疲労物質，あるいは中間代謝産物なとの影響に よって，心搏週期は第 3 次下降に移行するすのと 考える。50m, $100 \mathrm{~m}$ 水泳に扣いて, 自由型の場合 が他の泳法に比して，この一定水準の持続時間が 最す短かくて，第 3 次下降に早く移行しているの
は，ピッチが速いため筋運動が激しく，従って筋 からの疲労物質，あるいは中間代謝産物の生成が 多いためであろうと考える。

\section{5. steady state}

$50 \mathrm{~m}, 100 \mathrm{~m}, 400 \mathrm{~m}$ 水泳のいすれれの場合でも， 第 3 次下降に繶いて心搏週期は steady state に達 するが， steady state の出現時期は泳法の差およ び距離, すなわち運動の強度, 運動持紿時間など によっていくらか差があり，50m 水泳で $45 \pm 13$ 秒, $100 \mathrm{~m}$ 水泳で $71 \pm 15$ 秒, $400 \mathrm{~m}$ 水泳で $210 \pm$ 88 秒であって，また泳法の差，すなわちピッチが 速く運動が激しいはど, steady state は速く出現 している。steady state の出現時間を陸上競技の 場合と比較すると，水泳の場合の方が早く出現す るが，宇都山4) と野田 ${ }^{5)}$ は陸上競技の中・長距離 疾走における steady state の出現時期は距離が短 かいほど速く現われると報告しており，これは以 上の実験結果と一致する。しかし水泳がかなり激 しい全身運動であるにもかかわらず，心搏週期が 陸上競技のときほと短縮していない理由として， 次のようなことが考えられる。

1) 水泳では, 水の抵抗や浮力の影響により, 運動のスピードが减弱し，これに伴なって運動量 が少なくなる。

2) 水中運動であるため, 体温上䄯す陸上競技 のときほどではない。

3）本能的に浮力を維持するため，吸息を速く 呼息を徐々に行ならことにより，胸腔内圧の上䄯 が起る。

しかし,これらの諸要素のほかに, 運動の時間 す若干影響しているように思5。

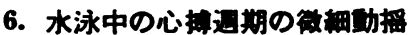

Fig. 1〜5 に見られるよ 5 K, $50 \mathrm{~m}, 100 \mathrm{~m}, 400$ $\mathrm{m}$ 水泳の 全経過において, 心搏週期の微細動摇 (0.01〜0.04 秒) が認められ, しかも $50 \mathrm{~m}$ および $100 \mathrm{~m}$ 水泳では, 自由型の場合が他の種目に比し て微細動摇がさく，かつ週期も短かい。これは ピッチの差, すなわち呼吸頻度の差によるるのと 思われる。陸上での疾走時, 心搏週期の微細動摇 が出現するが，これは心電図と呼吸運動の同時記 録をした宇都山4)の成績で，明らかに心搏週期の 呼吸性変動であることが認められた。したがって 水泳においても，この心搏週期の微細動摇は呼吸 
性の変動であろうと考えられる。

\section{7. ターン時における心拥期の変娌}

$100 \mathrm{~m}$ と $400 \mathrm{~m}$ 水泳のターン時において，心搏 週期が延長する傾向にあるが,ターンをする毎に， すなわち時間の経過とともにこのターン時の心搏 週期の延長は溸減して現われなくなる。土屋帛のの 実験では，息こらえのため，始め呼吸すると脈搏 数は一時多くなるが，呼吸の間にやや减少し，吸 息状態で呼吸を止めると，強い遅脈が起ると述へ ている。また, 著者ら ${ }^{(6)}$ は潜水泳の実験で, 潜水 すると著明に心搏週期の延長が起り，浮上すると 心搏週期は短縮すると報告した。したがって，著 者の実験におけるターン時の心搏週期の延長は, ターン時の潜水泳と止息のためと,ターン時の運 動中断など種々の要因によって，出現したるのと 考えられる。

\section{8. 水泳佛止後およひ回復期の心搏迥期の变功}

宇都山多 と野田 ${ }^{5)}$ は, 陸上競技の短距離疾走の 場合には, 運動停止後心搏週期は直には回復せず, 平均最小心搏週期を若干時間持続して後, 初期回 復に入ると述へ, 速水 ${ }^{19}$ は労作末期の脈搏数か 130 以上に達する労作を行なった場合における脈搏数 の回復過程は, 環境温度ならびに労作時間に大差 がなければ, 大体において労作末期の脈搏数が大 きいほど遅延する傾向を示すと報告している。著 者の実験で, $50 \mathrm{~m}$ 水泳ではすでにゴール直前にお いて，若干の心搏週期の延長を示していたが, 100 $\mathrm{m}$ と $400 \mathrm{~m}$ 水泳ではこのようなことはなく，心搏 週期は水泳停止後ただちに初期回復に入っている ものが多い。しかも回復所要時間も非常に短かい。 これは $400 \mathrm{~m}$ 水泳の場合, 医学部選手以外はほと んど国体選手であるために，常に激しいトレーニ ングをしており, 循環系の調節能力, および回復 能力が高まっているためであろう。

\section{400m 水泳における国体選手と医学部選手との 比䂭}

Hanson ら99は，スキー競技において，運動後 の心搏数の回復の速さは, その被験者のトレー二 ングの度合, および運動の激しさに関係があり, トレーニングされた競技者の心搏数は比較的速く 安静時の值に回復すると報告している。また, 宇

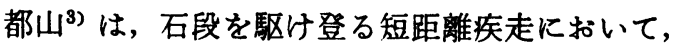
スポーツマンと非スポーツマンを較へると，心搏
動の初期回復はスポーツマソの方が速いと報告し ているが, 著者す $400 \mathrm{~m}$ 水泳において同様な結果 を得た。すなわち，国体選手と医学部選手の間に 次のような差を認めた。

i ）競技開始前の心搏週期の值に比し, 第 2 次 下降終点に打ける心搏週期の短縮度は国体選手の 方が大きい。

ii） steady state における心搏週期の值は，医 学部選手の方が短縮している。

iii）ゴール到達後, 国体選手はただちに初期回 復に入り, 回復所要時間も非常に短かいが, 医学 部選手はゴール到達後るなお数秒間, 停止前の心 搏週期の值を持続し，回復所要時間す長い。

このように種々の点でトレーニング奻果の差と 考えられる面があった。

10. $50 \mathrm{~m}, 100 \mathrm{~m}, 400 \mathrm{~m}$ 水泳の画醀による比較

スタート直後の心搏週期の急激な下降動摇は, $100 \mathrm{~m}$ 水泳の場合に出現率が高い。これは運動開 始前に心搏週期が延長しているため，運動開始に よって運動筋からの反射による心臟抑制神経の抑 制の解除が強くなって心搏週期は急激に短縮し， この短縮が強くなれば分時搏出量る增加して反射 的に心搏週期の延長が起るといろ一連の現象の反 復生起によって, 著明な下降動摇が出現したるの と考える。

また，心搏週期が一定水準に達するまでの時間 は, $50 \mathrm{~m}$ 水泳ではスタート後 $11 \pm 3$ 秒で最す早 く,400m では $22 \pm 11$ 秒で最も遅い。この一定水 準は, 運動筋からの反射で起った自律神経緊張の アンバランスが調整され安定した状態を示するの と考えられ，この水準に達するまでの時間は，運 動開始時の負荷の強弱に関係するのであろらと考 える。すなわち, スタート時の負荷の強さは, 距 離が短かいほど強くなるのが普通であって，負荷 が強く加わると心搏週期す早く強く短縮するか ら, 運動初期の心搏週期の短縮の強さ, すなわち 負荷が強いほど，先に述べたよ5に心搏週期の急 激かつ著明な下降動摇を起すが，一方それだけ早 く自律神経緊張のバランス調整が行なわれて，一 定水準に達する時間が早くなるのではないかと考 える。

steady state に達する時間も水泳距離により差 があり，又運動の強さが激しいほど早く steady 
state 飞達し，しかも心搏週期そのものも運動が 激しいほど著明な短縮を示すのは当然であろう。 11. 泳法による比較

$50 \mathrm{~m}, 100 \mathrm{~m}$ 水泳開始後の心搏週期の急下降(急 短縮)終点の心搏週期の值は自由型で最も小さい。 すなわち心搏週期が最す強く短縮しているが，平 泳，背泳，バタフライでは自由型と比較して，急 下降終点に打ける心搏週期は短縮の程度が少な く，又一定水準の持続時間も長く，しかもそのと きの心搏週期の值す，自由型のすのが他の泳法で のそれらに比してょり小であり，その持続時間す 短かく, steady state に達する時間も最も早い。 このような種々の点から，自由型が全身運動とし ては最も激しく，心蔵への負荷も最す強い種目で あると考えられる。

\section{要約}

著者らの考案した心電図水中無線搬送記録装置 を使用して, $50 \mathrm{~m}, 100 \mathrm{~m}, 400 \mathrm{~m}$ 水泳で, 自由型, 平泳, 背泳, ハタフライの 4 種目につき，国体選 手扰よび医学部学生など合計 24 名を被検者とし て，25m プールを使用して，水泳中の心電困を記 録した。この心電図記録から水泳中の心搏週期の 変動経過図を作り，心搏週期の変動経過について 考察して，次の結論を得た。

1）水泳中の心搏週期の変動経過は，初期の階 段状下降(短縮) とか，第 2 次下降，第 3 次下降， steady state の出現，および経過中の微細動摇の 出現などに若干の時間的な差はあるが，ほとんど 陸上競技の中・長距離疾走における変動経過と類 似している。

2）水泳中の心搏週期の変動経過は，スタート 前後の心搏週期の変動経過によって，次の 4 型に 分類し得る。

第 1 型：スタート後，心搏週期はゆるやかに階 段状に短縮し，ほとんど動摇のないるの。

第 2 型：水泳開始前に心搏週期か： 0.5 秒程度に 短縮しているにるかかわらず，急激な下降動摇が 出現するるの。

第 3 型 : スタート直後一時心搏週期が延長し, $1 \sim 2$ 回著明に動摇した後，ゆるやかな短縮に移 行するすの。

第 4 型：スタート前から動摇著しく、スタート
後 5 秒位でこれが著減し，ゆるやかな短縮に移行 するすの。

3）水泳開始直後，心搏週期の急下降（急短 縮), および下降（短縮）動摇の出現には，運動初 期の負荷の強さや開始前の心搏週期の大きさが関 係する。

4）水泳競技での心搏週期の初期下降（初期短 縮）は，陸上競技の疾走時はど急激ではないが， これはおそらく，水中で立位からスタートしたた め, 運動初期の負荷があまり強くなかったためで あろろ。

5） $50 \mathrm{~m}, 100 \mathrm{~m}, 400 \mathrm{~m}$ 水泳とも火，心搏週期 は第 2 次下降後，一定の水準を 10２0 秒間保つ が，この時期は，運動初期に筋からの反射により 起る抑制神経の抑制の解除によってアンバランス になった循環機能動態が，心臓反射および促進神 経の興奮によって調整され安定した状態となった 時期であろ5。

6)自由型水泳では,他の種目のときに比べて, スタート直後の心搏週期の急下降終点の値が最も 著明に短縮して扣り，一定水準の持続時間も短か く, steady state に達する時間，およびそのとき の心搏週期も最も短かい。このことから心臟への 負荷が最も強いのは種目としては自由型であるこ とが判った。

7）水泳中に $0.01 \sim 0.04$ 秒の心搏週期の微細 動摇が出現するが，これは呼吸性の 变動であろ 3 。

8） $100 \mathrm{~m}, 400 \mathrm{~m}$ 水泳で，ターン時に心搏週期 が一時延長するが，ターンをくりかえした後には この延長度は低減する。

9）国体選手と医学部選手の間に，トレーニン グ効果の差が非常によく現われており，特に循環 機能調節能力, および回復能力においてトレーニ ソグ効果が著明であった。

10）水泳は全身の激しい運動であるにかかわら ず，心搏週期の短樎が陸上競技疾走のときほど強 くないのは，水中運動であるために，身体推進の ための筋力発揮様式や水の抵抗, 浮力などの関係

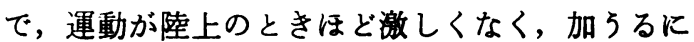
体温上昇率の低下, 胸腔内压の上其, 水圧などす 影響するのであろう。 
この論交の要旨は昭和 36 年 10 月第 15 回日本体 力医学会総会 (秋田), 昭和 37 年 10 月第 16 回日本 体力医学会総会 (岡山), 昭和 38 年 10 月第 17 回日 本体力医学会総会（山口）においてロ演発表した。

格りに臨み，岡芳包教授の御指導と御校閲に深甚 なる感謝を捧げるととるに，宇都山登講師，野田幸 作博士の御助言と御鞭撻, ならびにこの研究に対し て御協力を与えられた第 17 回国体德島県水涾㟟手, および德島大学医学部水泳部員の各位に厚く感謝の 意を表する。

\section{文}

1) 岡芳包, 宇都山登, 関根惟和, 野田幸作 (1955) : 運動中及びその後の心博数変動経過について (第 1 報)。体力科学, 第 5 巻, 第 1 号, 学 9

2) 岡芳包, 宇都山登, 関根惟和, 野田幸作 (1958) : 運動中の心電困の無線搬送について (続報)。 体力科学, 第 7 巻, 第 6 号, 学 299 300

3）宇都山登 (1961)：運動中の心搏週期 の 変動に 関する研究。第 I 編 短距離全力疾走中の心搏 週期の変動経過について。体力科学, 第 10 巻, 第 1 号, 81 89

4) 宇都山登 (1961) : 運動中の心搏週期 の変動に 関する研究。第II編 長距離全力疾走中の心搏 週期と呼吸の変動経過について。体力科学, 第 10 巻, 第 1 号, 90〜98

5）野田幸作 (1966)：テレメーター法による運動 中の心搏週期と呼吸運動の変動に関する研究。 第 I 編 $100 \mathrm{~m}$ 及び $400 \mathrm{~m}$ 全力疾走中の心搏週 期と呼四週期の変動経過について。四国医学雑 誌, 第 22 巻, 第 4 号, 617 626

6）野田幸作 (1966)：テレメーター法による運動 中の心搏週期と呼吸運動の変動に関する研究。 第 II 編 跳躍競技之投撽競技の心搏週期之呼吸 週期の変動経過について。四国医学雑誌, 第 22 巻, 第 4 号, 627 637

7）木村勝 (1970)：テレメーター法による運動中 の心博週期の変動に関する研究。第 1 編 重量 挙競技における心搏週期の変動経過について。 体力科学, 第 19 巻, 第 1,2 合併号, 6 17
8）猪飼道夫, 吉沢茂弘, 中川功哉 (1961)：トレ ッドミル法による全身持久性の評価について。 体力科学, 第 10 巻, 第 4 号, 227 238

9) Hanson, J. S., and B. S. Tabakin (1964): E. lectrocardiographic telemetry in skies anticipatory and recovery heart rate during competition. New Eng. J. Med., 271, 181 185

10）岡芳包, 宇都山登，野田幸作，木村勝（1962） : 短距離游泳中に括ける心搏週期の微細動摇経 過浽ついて体力科学, 第 11 巻, 第 1 号, 学 24

11）岡芳包, 宇都山登, 野田幸作, 木村勝 (1963) : $100 \mathrm{~m}$ 水泳における心搏週期の微細動摇経過 について。体力科学, 第 12 巻, 第 3 号, 学 118

12）岡芳包, 宇都山登, 野田幸作, 木村勝 (1964) : 400m 自由型水泳飞批ける心搏週期の变動経 過について。体力科学, 第 13 巻, 第 2 号, 学 58

13）岡芳包, 宇都山登, 野田幸作, 木村勝 (1962): 疾走, 跳羅, 水泳中の心電罒及び呼吸運動の無 線記録法による我々の研究。医用テレメーター シンポジゥム講演論文集, 52 2 63

14）岡芳包, 宇都山登 (1963) : スポーツと医学エレ クトロニクスー特にスポーツ医学におけるテレ メーターの応用について一診寮, 第 16 巻, 65 $\sim 72$

15) Hunt, E. A. (1963) : Electrocardiographic study of 20 champion swimmers before and after 110 yard sprint swimming competition. Canad. Med. Ass. J., 88, 1251 1253

16）岡芳包, 宇都山登, 野田幸作, 木村勝(1964): 潜水中の心搏週期の変動経過について。体力科 学, 第 13 巻, 第 2 号, 学 $57 \sim 58$

17）宮下充正, 松井秀治, 三浦望慶, 星川保, 亀井 貞次 (1969)：インターバル水涾中の休息期の 違いによる心搏数及び水泳スピードの变動。体 力科学, 第 18 巻, 第 1 号, $1 \sim 8$

18）土屋重郎 (1952)：呼吸運動と脈搏数（会）。日 本生理誌, 第 14 巻, 第 4 号, 176

19）速水清治郎 (1956)：脈搏数を指標として見た 筋労作の疲労恢復過程に就いて。体力科学, 第 6 巻, 第 5 号, 206 212 